\title{
PERAN WANITA SEBAGAI PENCARI NAFKAH KELUARGA DALAM PERSPEKTIF HUKUM ISLAM
}

\author{
(Studi Kasus di Desa Tempur Kecamatan Keling Kabupaten Jepara) \\ Luluk Shoviana \\ Peneliti George Mason University \\ Email: sofiana11@gmail.com \\ Zahrotun Navish Abdillah \\ Peneliti Fakultas Syariah dan Ekonomi Islam IPMAFA \\ Email: zahrotunnavishabdillah@gmail.com
}

\begin{abstract}
This study aims to determine the provisions of the role of women as female workers in the perspective of Islamic law, and the provisions of the role of women as female workers from the perspective of positive Indonesian law. The type of research used is field research using a qualitative approach. The data collection instrument use is the interview and observation studies. This study uses descriptive analytic. The results of this study indicate that The role of women as female workers in the perspective of Islamic law is basically permissible, due to seeking the living to fulfill the means of life is the right and obligation of both men and women as long as a wife does not neglect her obligations to her husband and children. The role of women as female workers in the perspective of positive Indonesian law is also permissible, because a woman is able to carry out activities both inside and outside the employment relationship to produce goods or services to meet their own needs and community needs.
\end{abstract}

Keywords: Women, Female Worker, Legal Views.

\begin{abstract}
Abstrak
Penelitian ini bertujuan untuk mengetahui ketentuan peran perempuan sebagai pekerja perempuan dalam perspektif hukum Islam, dan ketentuan peran perempuan sebagai pekerja perempuan dari perspektif bukum positif Indonesia. Jenis penelitian yang digunakan adalab penelitian lapangan dengan menggunakan pendekatan kualitatif. Instrumen pengumpulan data yang digunakan adalah wawancara dan observasi. Penelitian ini menggunakan analisis deskriptif analitik. Hasil penelitian ini menunjuk.kan babwa Peran perempuan sebagai pekerja perempuan dalam perspektif bukum Islam pada dasarnya diperbolebkan, karena mencari nafkah untuk memenubi sarana bidup adalab bak dan kewajiban lakilaki dan perempuan selama seorang istri tidak mengabaikan kewajibannya kepada suami dan anakanaknya. Peran perempuan sebagai pekerja perempuan dalam perspektif bukum positif Indonesia juga diperbolebkan, karena seorang perempuan mampu melakukan kegiatan baik di dalam maupun di luar
\end{abstract}


Luluk Sofiana dan Zahrotul N.A

bubungan kerja untuk menghasilkan barang atau jasa untuk memenubi kebutuban mereka sendiri dan kebutuban masyarakat.

Kata kunci: Wanita, Pencari Nafkah, Pandangan Hukum.

\section{A. Pendahuluan}

Pengertian keluarga memiliki dua dimensi yaitu keluarga sebagai ikatan kekerabatan antar individu. Pernyataan ini merujuk kepada mereka yang mempunyai hubungan darah dan pernikahan. Sebagai sinonim rumah tangga dalam makna ini ikatan kekerabatan amat penting, namun yang ditekankan adalah adanya kesatuhunian dan ekonomi.

Dalam Undang-Undang Nomor 10 tahun 1992 tentang Kependudukan dan Keluarga Sejahtera, pada bab ketentuan umum, keluarga dinyatakan sebagai unit terkecil dalam masyarakat yang terdiri dari suami istri, atau suami istri dengan anakanaknya, atau ayah dengan anaknya, atau ibu dengan anaknya. Adapun pengertian perkawinan (menurut UU No.1 tahun 1974 tentang Perkawinan Pasal 1), ialah "ikatan lahir batin antara seorang pria dengan seorang wanita sebagai suami istri dengan tujuan membentuk keluarga (Rumah Tangga) yang bahagia dan kekal berdasarkan Ketuhanan Yang Maha Esa. ${ }^{1}$

Rumah tangga yang diinginkan Islam, yakni rumah tangga sakinah, sebagai mana diisyaratkan Allah Subhanallabu Wa Ta'ala. Dalam surat Ar-Rum ayat 21 ada tiga kata kunci yang disampaikan oleh Allah dalam ayat tersebut, dikaitkan dengan rumah tangga yang ideal menurut Islam, yaitu sakinah (as-sakinah), mawaddah (al-mawaddah), dan rahmah (ar-rahmah). Ulama tafsir menyatakan bahwa As-sakinah adalah suasana damai yang melingkupi rumah tangga yang bersangkutan. Masing-masing pihak menjalankan perintah Allah Subbanallabu Wa Ta'ala dengan tekun, saling menghormati, dan saling toleransi. Dari suasana as-Sakinah tersebut akan muncul rasa saling mengasihi dan menyayangi (al-mawaddab) sehingga rasa tanggung jawab kedua belah pihak semakin tinggi, selanjutnya para mufasir mengatakan bahwa dari as-sakinah dan al-mawadah inilah nanti akan muncul ar-rahmah, yaitu keturunan yang sehat dan penuh berkat dari Allah

${ }^{1}$ Cholil Nafis, Fikih Keluarga, Menuju Keluarga Sakinah, Mawaddah,Warohmah Keluarga Sehat, Sejahtera dan Berkualitas, (Jakarta Selatan: Mitra Abadi Pres), Cet. ke-1, hlm 3. 
Subhanallahu $W a$ Ta'ala. Sekaligus sebagai pencurahan rasa cinta dan kasih suami istri dan anak-anak mereka. ${ }^{2}$

Lalu bagaimana dengan adanya kenyataan bahwa terdapat istri-istri yang memiliki kemampuan berpikir dan materi melebihi kemampuan suami? Quraish Shihab menyatakan bahwa hal ini merupakan suatu kasus yang tidak dapat dijadikan sebagai dasar untuk menetapkan suatu kaidah yang bersifat umum. Artinya, jika ditemukan keaadaan yang demikian, istri memiliki kelebihan dibanding suami maka tidak secara otomatis perempuan kemudian dapat memproklamirkan diri sebagai pemimpin atau kepala rumah tangga.

Dalam kehidupan sehari-hari, setiap keluarga memiliki kebutuhan yang harus dipenuhi baik kebutuhan primer, sekunder maupun tersier. Adakalanya seorang suami tidak memiliki cukup kemampuan untuk memenuhi kebutuhan tersebutnya. Dalam waktu dan kondisi sekarang berbeda, perempuan telah memiliki peluang yang sama dengan laki-laki untuk menjadi unggul dalam berbagai bidang kehidupan, bahkan secara ekonomi tidak lagi tergantung pada laki-laki. Banyak fenomena yang muncul pada masyarakat sekarang dijumpai perempuan berperan sebagai pencari nafkah utama bagi keluarganya. Seperti halnya di Desa Tempur Kecamatan Keling Kabupaten Jepara.

Dalam keadaan terhimpit ekonomi, banyak dari mereka bekerja di luar negeri menjadi Tenaga Kerja Wanita (TKW) seperti, Taiwan, Hongkong, Singapura, dan lain sebagainya, sehingga mereka mengabdikan diri mereka sebagai istri sekaligus pencari nafkah utama keluarga. Istri tidak dapat lagi melaksanakan hak dan kewajibannya sebagai istri dalam rumah tangga untuk sementara waktu. Munculnya fenomena tersebut mengakibatkan adanya dampak bagi kelangsungan hidup rumah tangga.

Dengan motivasi untuk mengubah nasib maupun adanya daya tarik upah yang relatif tinggi di luar negeri, mengakibatkan banyak para perempuan di Desa Tempur Keacamatan Keling Kabupaten Jepara rela menjadi Tenaga Kerja Wanita (TKW) di

${ }^{2}$ Cholil Nafis, Fikih Keluarga, Menuju Keluarga Sakinah, Mawaddah,Warohmah Keluarga Sehat, Sejabtera dan Berkualitas..., hlm 8-10. 
Luluk Sofiana dan Zahrotul N.A

luar negeri, bahkan para wanita yang sudah bersuami pun telah banyak menjadi Tenaga Kerja Wanita (TKW) di luar negeri.

Bersumber dari perspektif di atas, sejatinya dalam Islam mengajarkan bahwa pemberian nafkah keluarga diwajibkan kepada suami untuk menafkahi semua keluarganya. Bahkan hukumnya wajib bagi seorang suami untuk menafkahi semua anggota keluarganya sehingga tidak ada kekurangan dan sesuai dengan kemampuan seorang suami. Tetapi kenyataan banyak fenomena yang terjadi pada masyarakat kita khususnya di daerah-daerah kewajiban pemberian nafkah ini bergeser bahkan beralih kepada seorang istri yang seharusnya mereka tidak perlu mencari nafkah untuk keluarganya. Oleh karena itu, berdasarkan pernyataan di atas penulis merumuskan pernyataan sebagai berikut, "Bagaimana peran wanita sebagai Tenaga Kerja Wanita dari perspektif Hukum Islam? bagaimana peran wanita sebagai Tenaga Kerja Wanita dari perspektif Hukum Positif?”

Penelitian ini mempunyai tujuan untuk mengetahui ketentuan peran wanita sebagai Tenaga Kerja Wanita dari perspektif Hukum Islam serta untuk mengetahui ketentuan peran wanita sebagai Tenaga Kerja Wanita dari perspektif Hukum Positif. Adapun manfaat yang diharapkan penulis dari penelitian ini untuk memberikan sumbangan pemikiran bagi pengembangan ilmu syariah pada umumnya, khususnya hukum Islam mengenai peran wanita sebagai pencari nafkah keluarga, mengingat peran wanita yang sangat dijunjung luhur dalam hukum Islam. Dengan penelitian ini diharapkan bagi penulis dapat menambah wawasan dan pengetahuan mengenai realita kehidupan rumah tangga Tenaga Kerja Wanita (TKW) di Desa Tempur Kecamatan Keling Kabupaten Jepara.

\section{B. Landasan Teori}

\section{Pengertian Tenaga Kerja Wanita}

Tenaga Kerja Indonesia (TKI) adalah sebutan bagi warga negara Indonesia yang bekerja ke Luar Negeri seperti, Arab Saudi, Taiwan, Hongkong, Abudabi, Singapura, dan negara-negara lainnya. Istilah TKI sering kali di konotasikan dengan pekerja kasar, TKI perempuan sering disebut TKW (Tenaga Kerja Wanita). 
Meningkatnya frekuensi itu dalam pengamatan penulis disebabkan oleh dua faktor, pertama, faktor pendorong, dan kedua, faktor penarik. Faktor pendorong untuk melakukan migrasi dari satu daerah ke daerah lainnya adalah kondisi ekonomi daerah asal yang masih tergolong miskin dan tidak memungkinkan penduduknya untuk hidup layak, sementara beban hidup makin meningkat. Adapun faktor penariknya adalah adanya perbedaan upah yang sangat mencolok antara daerah asal dan daerah tujuan. ${ }^{3}$

Pada tanggal 9 Maret 2007 kegiatan operasional di bidang penempatan dan perlindungan TKW (Tenaga Kerja Wanita) di Luar Negeri dialihkan menjadi tanggung jawab BNP2TKI. Sebelumnya seluruh kegiatan operasional dibidang TKI (Tenaga Kerja Indonesia) di Luar Negeri dilaksanakan oleh Ditjen Pembinaan dan Penempatan Tenaga Kerja Luar Negeri (PPTKLN). Badan Nasional Penempatan dan Perlindungan Tenaga Kerja Indonesia yang selanjutnya disebut BNP2TKI adalah lembaga Pemerintah Non Departemen yang berada di bawah dan bertanggung jawab kepada presiden. BNP2TKI beranggotakan wakil-wakil instansi pemerintah terkait mempunyai fungsi pelaksanaan kebijakan di bidang penempatan dan perlindungan Tenaga Kerja Indonesia di Luar Negeri secara terkoordinasi dan terintegrasi, meliputi bidang ketenagakerjaan, keimigrasian, hubungan Luar Negeri, administrasi kependudukan, kesehatan, kepolisian, dan bidang lain yang dianggap perlu.

Di era globalisasi seperti sekarang ini, Penempatan dan Perlindungan TKW (Tenaga Kerja Wanita) paling tidak harus berpedoman kepada dua Undang-Undang yaitu Undang-Undang Nomer 32 Tahun 2004 tentang Pemerintah Daerah dan Undang-Undang Nomer 39 Tahun 2004 beserta peraturan dan pelaksanaannya. Apabila kedua Undang-Undang dan peraturan dan pelaksanaannya dipahami dengan benar, maka siapapun atau lembaga manapun tidak akan terjebak masalah kewenangan. Karena siapapun sebagai pemangku kewenangan bukan menjadi ukuran utama namun siapa yang mengambil peran paling benar dalam menjamin hak-hak TKI (Tenaga Kerja Indonesia).

\section{Bentuk-Bentuk Hak dan Kewajiban Suami Istri}

3 Abdul Haris, Memburu Ringgit Membagi Kemiskinan: Fakta di Balik Migrasi Orang Sasak ke Malaysia, (Yogyakarta: Pustaka Pelajar, 2002), hlm. 1. 
Luluk Sofiana dan Zahrotul N.A

Hikmah diciptakan Allah manusia berpasang-pasangan yang berlainan bentuk dan sifat, adalah agar masing-masing saling membutuhkan, saling memerlukan, sehingga dapat hidup berkembang selanjutnya. ${ }^{4}$ Mendambakan pasangan merupakan fitrah sebelum dewasa, dan dorongan yang sulit dibendung. Oleh karena itu, agama mensyariatkan agar dijalinnya pertemuan antara laki-laki dan perempuan, mengarahkan pertemuan itu sehingga terlaksananya perkawinan maka beralihlah kerisauan laki-laki dan perempuan menjadi ketentraman serta sakinah. ${ }^{5}$

Perjanjian yang dibuat oleh seorang muslim untuk menjadikan seorang muslimah sebagai istri, merupakan perjanjian yang dibuat atas nama Allah. Karena itu, hidup sebagai suami istri bukanlah semata-mata sebuah ikatan yang dibuat berdasarkan perjanjian dengan manusia, yaitu dengan wali dari pihak perempuan dan dengan keluarga perempuan secara keseluruhan, serta dengan perempuan itu sendiri, akan tetapi yang lebih penting lagi adalah membuat perjanjian dengan Allah. Maka dari itu, pernikahan adalah salah satu diantara tanda-tanda kekuasaan Allah. ${ }^{6}$

Rumah tangga yang menjadi surga dunia bukanlah identik dengan limpahan materi, kebahagiaan bukanlah sebuah kemustahilan untuk dicapai, sebab kebahagiaan merupakan pilihan dan buah dari cara berfikir dan bersikap. Maka dari itu, hanya dengan keduanya, diharapkapkan dapat menikmati manisnya cinta dan indahnya kasih sayang serta kerinduan. ${ }^{7}$

Jika akad nikah sah dan berlaku, maka ia akan menimbulkan akibat hukum, dan akan menimbulkan pula hak dan kewajiban suami istri. Hak dan kewajiban ada tiga macam yaitu:

a. Hak istri atas suami

Hak istri yang harus dipenuhi oleh suami terdiri dari hak kebendaan dan hak rohaniah. ${ }^{8}$

\footnotetext{
${ }^{4}$ Amir Taat Nasution,Rahasia Perkawinan Dalam Islam: Tuntunan Keluarga Bahagia, Jakarta: Pedoman Ilmu Jaya, Cet. Ke-3, 1994) hlm. 1.

${ }^{5}$ M. Quraish Shihab,Wawasan Al-qur'an, (Bandung: Mizan, Cet. Ke-11, 2000), hlm. 192.

${ }^{6}$ Rusli Amin, Rumabku Surgaku: Sukses Membangun Keluarga Islami, (Jakarta: Al-Mawardi Prima, Cet. Ke-11, 2003), hlm. 24.

7 Lembaga Darut-tauhid, Kiprah Muslimah Dalam Keluarga Islam, Terj. A. Chumaidi Umar, (Bandung: Mizan, Cet. Ke-1, 1990), hlm.82.

8 Sayyid Sabiq, Fiqih Sunnah Jilid VII, Terjemah Fiqih Sunnah, (Bandung, PT. Al Ma'arif, t.t), hlm. 53.
} 
1) Hak kebendaan
a. Mahar (Mas Kawin)
b. Belanja

2) Hak bukan kebendaan (Rohaniyah)

a. Mendapatkan pergaulan secara baik dan patut. ${ }^{9}$

b. Mendapatkan perlindungan dari segala sesuatu yang mungkin melibatkannya pada suatu perbuatan dosa dan maksiat atau ditimpa oleh suatu kesulitan dan mara bahaya. Mendapatkan rasa tenang, kasih sayang, dan rasa cinta dari suami. ${ }^{10}$

c. Pembatasan kelahiran

Dalam keadaan istimewa Islam tidak menghalangi pembatasan kelahiran dengan cara pengobatan guna mencegah kehamilan atau cara-cara lain. Pembatasan kelahiran ini dibolehkan bagi laki-laki yang sudah banyak anaknya yang sudah tidak sanggup lagi memikul beban pendidikan anaknya dengan sebaik-baiknya, begitu pula kalau istri keadaannya lemah atau mudah hamil atau suami dalam keadaan miskin.

3) Hak bersama-sama

a) Halal saling bergaul dan bersenang-senang diantara keduanya.

b) Haram melakukan perkawinan

Setelah akad nikah di sini terjadi hubungan suami dengan keluarga istrinya dan sebaliknya hubungan istri dengan keluarga suaminya. Akibatnya istri haram dinikahi oleh ayah suaminya, datuknya, anaknya, cucunya, begitu juga ibu istrinya, anak perempuannya dan seluruh cucunya haram dinikahi oleh suaminya.

4) Hak untuk saling mendapat warisan

Akibat dari ikatan perkawinan yang sah adalah bila salah seorang meninggal dunia sesudah sempurnanya ikatan perkawinan maka akan mendapatkan warisan.

\footnotetext{
9 Amir Syarifudin Hukum Perkawinan di Indonesia Antara Fiqih Munaqahat dan Undang-Undang Perkawinan, (Jakarta: Kencana, Edisi I, Cet I, 2006), hlm. 160. Perkawina..., hlm. 161.
} 
Luluk Sofiana dan Zahrotul N.A

b. Kewajiban suami istri

Selain hak bersama-sama suami istri, dalam fiqh juga disebutkan mengenai tanggung jawab diantara keduanya secara bersama-sama setelah terjadinya perkawinan. Kewajiban itu ialah:

(a) Memelihara dan mendidik anak keturunannya yang lahir dari perkawinan tersebut.

(b) Membina kehidupan rumah tangga yang sakinah, mawaddah dan warohmah. ${ }^{11}$

\section{Hak dan Kewajiban Suami Istri Menurut Perundang-Undangan}

a. Hak dan Kewajiban Suami Menurut Undang-Undang Perkawinan Nomor 1 Tahun 1974

Hak dan kewajiban suami istri dalam rumah tangga telah diatur menurut Undang-Undang Perkawinan No.1 Tahun 1974. Pembahasan hak dan kewajiban suami istri diatur dalam BAB VI Pasal 30 sampai Pasal 34.

Pasal 30 Undang- Undang Perkawinan berbunyi suami istri memikul kewajiban yang luhur untuk menegakkan rumah tangga yang menjadi sendi dasar dari susunan masyarakat.

Pasal 31 UU No. 1 Tahun 1974 tentang Perkawinan menyatakan:

1) Hak dan kedudukan istri adalah seimbang dengan hak dan kedudukan suami dalam kehidupan rumah tangga dan pergaulan hidup bersama dalam masyarakat.

2) Masing-masing pihak berhak untuk melakukan perbuatan hukum.

3) Suami adalah kepala keluarga dan istri ibu rumah tangga.

Selanjutnya Pasal 32 Undang-Undang Perkawinan menegaskan, bahwa:

1) Suami istri harus mempunyai kediaman yang tetap.

2) Rumah tempat kediaman yang dimaksud dalam ayat (1) pasal ini ditentukan oleh suami istri bersama.

11 Amir Syarifudin Hukum Perkawinan di Indonesia Antara Fiqih Munaqahat dan Undang-Undang Perkawinan..., hlm. 163-164. 
Dalam pasal 33 Undang- Undang Perkawinan menegaskan, "Suami istri wajib saling mencintai, hormat menghormati, setia dan memberi bantuan lahir batin yang satu kepada yang lain".

Pasal 34 Undang- Undang Perkawinan disebutkan:

1) Suami wajib melindungi istrinya dan memberikan segala sesuatu keperluan hidup berumah tangga sesuai dengan kemampuannya.

2) Istri wajib mengatur urusan rumah tangga sebaik-baiknya.

3) Jika suami atau istri melalaikan kewajibannya masing-masing dapat mengajukan gugatan kepada pengadilan. ${ }^{12}$

\section{b. Hak dan Kewajiban Suami Istri Menurut Kompilasi Hukum Islam}

Selain definisi diatas hak dan kewajiban suami istri juga dijelaskan dalam Kompilasi Hukum Islam (KHI), sebagai berikut:

Pasal 77 KHI menyatakan bahwa:

1) Suami istri memikul kewajiban yang luhur untuk menegakkan rumah tangga yang sakinah, mawaddah, warahmah yang menjadi sendi dasar dan susunan masyarakat.

2) Suami istri wajib saling mencintai, hormat menghormati, setia dan memberi bantuan lahir batin yang satu kepada yang lain.

3) Suami istri memikul kewajiban untuk mengasuh dan memelihara anak-anak mereka, baik mengenai pertumbuhan jasmani, rohani, maupun kecerdasannya dan pendidikan agamanya.

4) Suami istri wajib memelihara kehormatannya.

5) Jika suami istri melalaikan kewajibannya, masing-masing dapat mengajukan gugatan kepada Pengadilan Agama.

Pasal 78 KHI menjelaskan bahwa:

1) Suami istri harus mempunyai tempat kediaman yang tetap.

2) Rumah kediaman yang dimaksud ayat (1), ditentukan oleh suami istri.

Sedangkan kedudukan suami istri dijelaskan dalam Pasal 79 KHI, bahwa:

1) Suami adalah kepala keluarga dan istri ibu rumah tangga.

${ }^{12}$ Undang-Undang Perkawinan di Indonesia, Arkola, Surabaya, hlm. 15-16. 
Luluk Sofiana dan Zahrotul N.A

2) Hak dan kedudukan istri adalah seimbang dengan hak dan kedudukan suami dalam kehidupan rumah tangga dan pergaulan hidup bersama dalam masyarakat.

3) Masing-masing pihak berhak untuk melakukan perbuatan hukum.

Kemudian kewajiban suami dijelaskan dalam Pasal 80 KHI, sebagai berikut:

1) Suami adalah pembimbing terhadap istri dan rumah tangganya, akan tetapi mengenai hal-hal urusan rumah tangga,yang penting-penting diputuskan oleh suami istri bersama.

2) Suami wajib melindungi istrinya dan memberikan segala sesuatu keperluan hidup berumah tangga sesuai dengan kemampuannya.

3) Suami wajib memberikan pendidikan agama kepada istrinya, dan memberi kesempatan belajar pengetahuan yang berguna, dan bermanfaat bagi agama dan bangsa.

4) Sesuai dengan penghasilan suami menanggung nafkah, kiswah, dan tempat kediaman bagi istri, biaya rumah tangga, biaya perawatan, dan biaya pengobatan bagi istri dan anak, biaya pendidikan bagi anak.

5) Kewajiban suami terhadap istrinya seperti tersebut pada ayat (4) huruf a dan b diatas mulai berlaku sesudah ada tamkin sempurna dari istrinya.

6) Istri dapat membebaskan suaminya dari kewajiban terhadap dirinya sebagaimana tersebut pada ayat (4) huruf a dan b.

7) Kewajiban suami sebagaimana dimaksud ayat (2) gugur apabila istrinya nusyuz:

Kemudian tempat kediaman yang dimaksud dalam pasal $81 \mathrm{KHI}$, sebagai berikut:

1) Suami wajib menyediakan tempat kediaman bagi istri dan anak-anaknya, atau mantan istri yang masih dalam iddah.

2) Tempat kediaman adalah tempat tinggal yang layak untuk istri selama dalam ikatan perkawinan, atau dalam iddah talak atau iddah wakaf.

3) Tempat kediaman disediakan untuk melindungi istri dan anak-anaknya dari gangguan pihak lain, sehingga mereka merasa aman dan tentram. Tempat 
kediaman juga berfungsi sebagai tempat penyimpanan harta kekayaan, sebagai tempat menata dan mengatur alat-alat rumah tangga.

4) Suami wajib melengkapi tempat kediaman sesuai dengan kemampuannya, serta disesuaikan dengan keadaan lingkungan tempat tinggalnya, baik berupa alat perlengkapan rumah tangga maupun sarana penunjang lainnya.

Adapun kewajiban seorang istri kepada suaminya dijelaskan dalam pasal

$83 \mathrm{KHI}$, sebagai berikut:

1) Kewajiban utama bagi seorang istri adalah berbakti lahir batin pada suami di dalam batas-batas yang dibenarkan oleh hukum Islam.

2) Istri menyelenggarakan dan mengatur keperluan rumah tangga sehari-hari dengan sebaik-baiknya.

Pasal 84 KHI menerangkan bahwa:

1) Istri dapat dianggap nusyur, ${ }^{13}$ jika ia tidak mau melaksanakan kewajiban sebagaimana dimaksud dalam pasal 83 ayat (1) kecuali dengan alasan yang sah.

2) Selama istri dalam Nusyur, kewajiban suami terhadap istrinya tersebut pada pasal 80 ayat (4) hurufa dan b tidak berlaku kecuali hal-hal untuk kepentingan anaknya.

3) Kewajiban suami tersebut pada ayat (2) diatas berlaku kembali sesudah istri tidak Nusyur:

4) Ketentuan ada atau tidak adanya dari istri harus didasarkan atas bukti yang sah. ${ }^{14}$

\section{Metode Penelitian}

Adapun metode penelitian yang digunakan penulis dalam penelitian ini adalah sebagai berikut:

1. Jenis Penelitian

Jenis penelitian dalam penyusunan penulisan ini adalah penelitian lapangan, yaitu merupakan salah satu metode pengumpulan data dalam penelitian kualitatif yang tidak memerlukan pengetahuan mendalam akan literatur yang digunakan dan kemampuan tertentu dari pihak peneliti.

\section{Sifat Penelitian}

${ }^{13}$ Nusyuz adalah pembangkangan suami atau istri terhadap pasangan karena suami atau istri telah melanggar hak-hakpasangan.

${ }^{14}$ Kompilasi Hukum Islam (KHI). 
Luluk Sofiana dan Zahrotul N.A

Penelitian ini bersifat deskriptif yaitu suatu penelitian untuk memberikan data yang ada sedetail mungkin tentang manusia, keadaan, atau gejala-gejala yang terjadi. ${ }^{15}$

3. Pendekatan Penelitian

Penelitian ini merupakan penelitian yang menggunakan pendekatan kualitatif yaitu suatu penelitian yang bertujuan meneliti hakikat dan makna.

4. Sumber Data

Dalam penelitian ini menggunakan sumber primer dan data sekunder. Sumber data primer disini diperoleh secara langsung di lapangan/tempat penelitian meliputi wawancara yang tidak terikat dan observasi. Sumber data sekunder yaitu data yang sumber datanya diperoleh dari bahan hukum primer, bahan hukum sekunder, dan bahan hukum tersier, baik hukum positif Indonesia maupun hukum Islam.

6. Teknik Pengumpulan Data

Dalam penelitian ini, teknik pengumpulan data yang penulis gunakan adalah wawancara tidak terikat, observasi dan studi dokumen.

7. Teknik Analisis Data

Teknik analisis data adalah suatu uraian tentang cara-cara analisis, yaitu kegiatan mengumpulkan data kemudian diadakan pengeditan terlebih dahulu, untuk selanjutnya dimanfaatkan sebagai bahan analisis yang sifatnya kualitatif. Analisis kualitatif menghasilkan data deskriptif yang merupakan kata-kata, atau tulisan.

\section{Hasil Penelitian}

\section{Kondisi Geografis dan Demografis}

Desa Tempur merupakan salah satu desa yang berada di wilayah Kecamatan Keling, Kabupaten Jepara, Provinsi Jawa Tengah dengan luas wilayah 2.416.5 Ha, dari keseluruhan luas daerah yang ada di Desa Tempur. Secara geografis Desa Tempur terdiri dari pegunungan yang mayoritas masyarakatnya bertani. Kondisi umum diwilayah Desa Tempur adalah wilayah subur untuk pertanian dan aman dari erosi. Desa Tempur sudah sangat terbuka dengan dunia luar walaupun alat transportasi dan kondisi jalan yang kurang baik. Desa Tempur meliputi tujuh

${ }^{15}$ Soerjono Soekanto, Pengantar Penelitian Hukum..., hlm. 10 
perkampungan diantaranya: Miren, Petung, Glagah, Pekoso, Karang Rejo, Duplak, dan Nggodang.

Orbitasi atau jarak tempuh dari Desa Tempur ke Kecamatan adalah kurang lebih $20 \mathrm{Km}$, jarak tempuh ke Kabupaten $50 \mathrm{Km}$, sedangkan jarak tempuh Desa Tempur ke Provinsi Jawa Tengah kurang lebih $123 \mathrm{Km}$ dan jarak ke ibu kota Jakarta yakni kurang lebih $579 \mathrm{Km}$ jika melewati rute tercepat dan perjalanan lancar.

Penduduk desa Tempur terdiri dari 1.230 Kepala Keluarga dengan jumlah penduduk seluruhnya 3.572 jiwa yang terdiri atas penduduk laki-laki sebanyak 1.737 jiwa dan penduduk perempuan sebanyak 1.835 jiwa. Dari semua penduduk tersebut bermukim dalam 1.056 rumah.

\section{Peran Wanita Sebagai Tenaga Kerja Wanita Dari Perspektif Hukum Islam}

Dari hasil penelitian yang penulis lakukan di Desa Tempur Kecamatan Keling Kabupaten Jepara, berikut ini akan penulis jelaskan mengenai peran istri di Desa Tempur Kecamatan Keling Kabupaten Jepara menjadi TKW (Tenaga Kerja Wanita) ke Luar Negeri untuk memenuhi nafkah keluarga berdasarkan al-Qur'an, Hadis, dan Ijma' Ulama.

\section{a. Landasan Al-Qur'an Atas Peran Wanita Sebagai Tenaga Kerja Wanita}

Jika dipahami secara benar, tidak ada satupun ayat-ayat Al-Qur'an yang menginformasikan bahwa perempuan adalah bawahan laki-laki. Di dalam alQur'an jelas dinyatakan bahwa dihadapan Allah Subhanallahu Wata'ala semua manusia adalah sama baik laki-laki maupun perempuan mempunyai kedudukan setara yang membedakan hanyalah ketakwaan

Lafadz Qamwamun pada al-Qur'an surat an-Nisa ayat 34 mufasir ditafsirkan bahwa suami adalah pelindung, pemimpin, penanggung jawab, dan pengatur konteks keluarga. Kadang ayat tersebut dijadikan sebuah landasan pengharaman bagi perempuan untuk diwilayah publik (lingkungan kerja) padahal menurut Aminah Wadud, Azizah al-Hibri dan Riffat Hasan yang dijelaskan dalam buku Sayyid Sabiq menyatakan bahwa Qawwamun mempunyai arti pencari nafkah atau orang-orang yang menyediakan sarana pendukung atau sarana kehidupan. Dengan 
Luluk Sofiana dan Zahrotul N.A

demikian, perempuan juga tidak ada larangan untuk bekerja, karena laki-laki hanya jadi pemimpin atas semua perkara.

Bila kita perhatikan bentuk-bentuk hak dan kewajiban suami istri menurut kompilasi Hukum Islam jika akad nikah sudah sah dan berlaku, maka ia akan menimbulkan akibat hukum, dengan demikian akan menimbulkan pula hak serta kewajiban selaku suami istri. Salah satu hak istri yang harus dipenuhi oleh seorang suami adalah hak kebendaan,yaitu belanja (nafkah). ${ }^{16}$ Yang dimaksud dengan belanja (nafkah) di sini yaitu memenuhi kebutuhan makan, tempat tinggal, pakaian, pengobatan istri, dan pembantu rumah tangga jika ia seorang kaya. Hukum memberi belanja kepada istri adalah wajib. ${ }^{17}$

Mengenai kadar nafkah pada dasarnya adalah dapat mencukupi keperluan secara wajar, tetapi dalam beberapa kasus seperti halnya di Desa Tempur Kecamatan Keling Kabupaten Jepara ditemukan besarnya nafkah yang diberikan suami kepada istri tidak mencukupi kebutuhan, sehingga banyak para istri yang memutuskan untuk bekerja ke Luar Negeri untuk menjadi TKW (Tenaga Kerja Wanita) demi merubah hidup keluarganya menurut ekonomi.

\section{Landasan Al-Hadis Atas Peran Wanita Sebagai Tenaga Kerja Wanita}

Kewajiban suami memberikan nafkah kepada istri bukanlah didasarkan pada budaya, tradisi atau adat istiadat. Islam menetapkan memberi nafkah kepada istri sebagai suatu perintah dalam islam. Yaitu perintah yang dikeluarkan sendiri oleh Allah Subhanallahu Wata'ala kepada hamba-Nya. Oleh karena itu, seorang suami yang tidak memberikan nafkah kepada istrinya telah berdosa kepada istri dan berdosa kepada Allah Subhanallahu Wata'ala.

Kondisi ekonomi seseorang sering kali mengurangi rasa kekhawatiran yang seharusnya ada pada diri masing-masing orang. Sebaliknya justru akan menyisihkan segala kekhawatiran dan padan perasaan pada resiko yang akan mengancam dirinya sekalipun. Mereka adalah orang-orang lemah, yang tidak

53.

${ }^{16}$ Sayyid Sabiq, Fiqih Sunnah Jilid VII, Terjemah Fiqih Sunnah, (Bandung, PT. Al Ma'arif, 2003), hlm.

${ }^{17}$ Sayyid Sabiq, Fiqih Sunnah Jilid VII, Terjemah Fiqih Sunnah..., hlm. 77. 
memiliki kuasa dihadapan tawaran-tawaran yang paling membahayakan sekalipun. Ini adalah tugas-tugas orang yang kuat dan memiliki kuasa dalam masyarakat yaitu, negara yang seharusnya memberikan jaminan perlindungan trhadap mereka orang-orang yang lemah dalam hal ekonomi.

Berdasarkan pada kaidah fiqh keempat yang artinya: "Apabila bertentangan dua kebaikan, maka perhatikan mana yang lebib besar mudharatnya dengan dikerjakean yang lebih ringan kepada mudharatnya"18

Dalam kaidah ini disebutkan apabila suatu ketika datang secara bersamaan maka harus dipilih terlebih dahulu manakah mufsadat itu yang lebih kecil atau lebih ringan. Setelah ini diketahui, maka yang mudharat-nya lebih besar atau berat harus ditinggalkan dan dikerjakan yang lebih ringan mudharat-nya. ${ }^{19}$ Berdasarkan kaidah fiqh tersebut maka profesi sebagai Tenaga Kerja Wanita untuk para istri di Desa Tempur Kecamatan Keling Kabupaten Jepara diperbolehkan. Karena ketika istri menekuni profesi sebagai Tenaga Kerja Wanita di Luar Negeri manfaat yang didapat jauh lebih banyak daripada mudharat-nya.

\section{Landasan Ijma' Ulama Atas Peran Wanita Sebagai Tenaga Kerja Wanita}

Banyak ulama yang mendukung penuh bagi para wanita (istri) untuk tetap tinggal dirumah dan bekerja untuk anak dan suaminya. Mereka berpendapat bahwa istri yang bekerja di luar rumah akan banyak mendatangkan fitnah sehingga mereka melarangnya kecuali dalam keadaan terpaksa.

Keempat imam madzhab yaitu Maliki, Hambali, Syafi'i, dan Hanafi sepakat bahwa memberikan nafkah itu hukumnya wajib setelah adanya ikatan dalam sebuah pernikahan. Akan tetapi keempat imam madzhab memiliki perbedaan mengenai kondisi, waktu dan tempat. Perbedaan tersebut terletak pada waktu, ukuran, siapa yang wajib mengeluarkan nafkah dan kepada siapa $1420 \mathrm{H}$.

${ }^{18}$ Al Qowa'idul Fiqhiyah, Syaikh 'Abdurrahman bin Nashir As Sa'di, terbitan Darul Haromain, tahun hlm. 30 .

\footnotetext{
19 Asjmuni A. Rahman, Qaidab-qaidab Fiqh (Qawidul FIqbiyab), Cet-1 (Jakarta, Bulan Bintang, 1976),
} 
Luluk Sofiana dan Zahrotul N.A

sajakah nafkah itu wajib diberikan. Keempat imam madzhab sepakat bahwa nafkah meliputi sandang, pangan dan tempat tinggal. ${ }^{20}$

Adapun pendapat dari masing-masing ulama sebagai berikut:

a. Mazhab Imam Maliki

Menurut Mazhab Imam Maliki mencukupi nafkah keluarga merupakan kewajiban ketiga dari seorang suami setelah membayar mahar dan berlaku adil kepada istri, baik karena cerai atau meninggal dunia maka harta asli istri tetap menjadi milik istri dan harta milik suami tetap menjadi milik suami. Menurut Madhzab Maliki waktu berlakunya pemberian nafkah wajib apabila suami sudah mengumpuli istrinya. ${ }^{21}$

d. Mazhab Imam Hanafi

Menurut Mazhab Imam Hanafi mencukupi nafkah istri merupakan kewajiban kedua setelah membayar mahar dalam pernikahan. Nafkah diwajibkan bagi suami selama istri sudah baligh.

e. Mazhab Syafi'i

Menurut Mazhab Imam Syafi'i hak istri sebagai kewajiban suami kepada istrinya adalah membayar nafkah. Nafkah tersebut meliputi sandang, pangan, dan tempat tinggal.

c. Mazhab Imam Hambali

Menurut Mazhab Imam Hambali suami wajib membayar atau memenuhi nafkah terhadap istrinya jika istri tersebut sudah dewasa dan sudah dikumpuli oleh suami, istri menyerahkan diri sepenuhnya kepada suaminya. ${ }^{22}$

\section{Pembahasan Tentang Wanita Sebagai Tenaga Kerja Wanita di Desa} Tempur Kecamatan Keling Kabupaten Jepara

Fakta yang terjadi di Desa Tempur Kecamatan Keling Kabupaten Jepara menunjukkan bahwa peran perempuan sebagai seorang istri dan ibu

20 Abdur Rohmab Al Jaziri, Kitab Figh Al-Madzabib Al-Arba'ah, (juz 4, Al-Maktabah, Al-Tijariyyah Al-Kubro, Mesir, 1969), hlm. 553. hlm. 41.

${ }^{21}$ Imam Qodzi Abu Walid Muhammad Bin ahmad, Bidayatul Mujtahid, (Mesir: Dar Al-Fikr, Juz 3),

22 Abdur Rohman Al-Jiziri, Kitab Fiqh Al-Madzabib Al-Arba’ah, (Juz 4), hlm. 553. 
rumah tangga mengalami perubahan, sebelumnya kebanyakan mereka hanya berada di rumah hanya untuk mengurusi urusan keluarganya. Aktivitasnya seharihari hanya melaksanakan pekerjaan rumah saja. Namun saat ini seiring berkembangnya zaman, situasi dan kondisi yang berbeda. Banyak dari mereka bekerja untuk memenuhi kebutuhan nafkah keluarga ketika kehidupan rumah tangganya mengalami persoalan dalam hal ekonomi. Minimnya keahlian yang dimiliki sebagian besar dari mereka akhirnya memilih pekerjaan sebagai Tenaga Kerja Wanita (TKW) ke Luar Negeri.

Menurut ibu Sulasmi yang merupakan salah satu warga Desa Tempur yang pernah bekerja ke Taiwan, menjadi TKW merupakan satu pilihan yang tepat walaupun dibalik dari pilihan itu terdapat berbagai macam resiko yang harus dihadapi salah satunya adalah mendapatkan majikan yang kurang baik. Profesi menjadi TKW mengakibatkan istri jauh dari anggota keluarganya yaitu suami dan anak-anaknya. Keadaan ini membuat istri tidak dapat menjalankan kewajibannya walaupun sementara waktu. Padahal kebahagiaan keluarga itu dapat tumbuh jika istri dapat melaksanakan kewajiban terhadap suami dan anakanaknya. Kewajiban ini sangat suci dan mulia karena dengan memberikan perhatian penuh kepada anak-anaknya dengan baik akan memunculkan generasi penerus yang baik pula. ${ }^{23}$

Dengan munculnya berbagai kasus tersebut seperti di atas, fatwa MUI (Majelis Ulama Indonesia) menyebutkan perempuan yang meninggalkan keluarga untuk bekerja ke Luar Kota atau ke Luar Negeri, pada prinsipnya boleh sepanjang disertai mahrom (keluarga), lembaga atau kelompok perempuan yang terpercaya. Jika tidak disertai mahrom (keluarga) hukumnya haram kecuali tidak dalam keadaan darurat yang benar-benar dapat dipertanggung jawabkan secara Syar'i serta dapat menjamin keamanan dan kehormatan TKW. Kewajiban

${ }^{23}$ Ukasyah Athibi, Wanita Mengapa Merosot Akhlaknya, (Jakarta: Gena Insani, 1998), hlm. 27-28. 
Luluk Sofiana dan Zahrotul N.A

tentang penjaminan keamanan ini diwajibkan kepada pemerintah, lembaga dan pihak lain dalam pengiriman TKW untuk melindunginya. ${ }^{24}$

Pengamanan dan perlindungan sosial adalah kewajiban negara melalui sistem politik dan hukumnya untuk memberikan jaminan keamanan dan perlindungan bagi setiap warganya, baik laki-laki maupun perempuan. Negara dituntut untuk mewujudkan pengamanan sosial agar masyarakat secara individual maupun kolektif dapat menjalankan aktivitasnya sehari-hari dengan aman dan tenang. Negara tidak berhak melarang warganya untuk melakukan aktivitas warga apalagi mengangkat kepentingan yang paling mendasar baik ekonomi, sosial, politik, maupun pendidikan. ${ }^{25}$

Dari keterangan di atas sangat tepat apabila sebuah keluarga tidak ada yang menanggung kebutuhan hidup, maka perempuan (istri) bekerja untuk mencukupinya. Maka, ketika suami tidak mampu memenuhi kebutuhan nafkah keluarga, berarti istri mempunyai peranan penting dalam hal urusan ekonomi keluarga. Dengan bekerja menjadi Tenaga Kerja Wanita (TKW) kebutuhan rumah tangga dapat terpenuhi. Padahal dapat diketahui dengan melihat pekerjaan tersebut, keadaan tidak memungkinkan istri untuk dapat melaksanakan kewajibannya sebagai seorang istri sekaligus ibu bagi anak-anaknya, walaupun sifatnya hanya sementara waktu.

\section{E. Peran Wanita Sebagai Tenaga Kerja Wanita Dari Perspektif Hukum Positif}

Pengertian tenaga kerja dalam Undang-Undang Nomor 13 Tahun 2003 tersebut menyempurnakan pengertian tenaga kerja dalam Undang-Undang Nomor 14 tahun 1969 Tentang Ketentuan Ketentuan Pokok Ketenagakerjaan yang memberikan pengertian "Tenaga Kerja adalah setiap orang yang mampu melakukan pekerjaan baik di dalam maupun di luar hubungan kerja guna menghasilkan barang atau jasa untuk memenuhi kebutuhan masyarakat." Dengan demikian dapat kita simpulkan bahwa pengertian tenaga kerja wanita adalah seorang perempuan yang mampu melakukan

24 Himpuanan Fatwa Majelis Ulama Indonesia,Bagian Proyek Sarana dan Prasarana Produk Halal, Direktur Jenderal Bimbingan Masyarakat Islam dan Penyelenggaraan Haji Departemen Agama RI, 2003, hlm. 281.

${ }^{25}$ Faqihudin Abdul Qodir, dkk, hlm. 225 
kegiatan/pekerjaan baik di dalam maupun di luar hubungan kerja guna menghasilkan barang atau jasa untuk memenuhi kebutuhan sendiri maupun kebutuhan masyarakat.

Seiring dengan perkembangan jaman dan tuntutan hidup yang semakin tinggi membuat wanita harus ikut menanggung beban ekonomi keluarga. Kebutuhan yang mendesak mampu mendobrak tradisi dan pandangan genderitas. Perlu adanya sebuah alternatif yang mampu memecahkan persoalaan ekonomi keluarga dan salah satu jalannya adalah menjadi pembantu rumah tangga di luar negeri. Secara eksplisit di Indonesia telah terjadi ketimpangan yaitu antara jumlah tenaga kerja dengan lapangan pekerjaan yang tersedia tidak seimbang. Rendahnya penyerapan tenaga kerja bagi wanita menyebabkan para wanita berfikir untuk menjadi TKW ke luar negeri agar dapat membantu perekonomian keluarga. Setiap TKW memiliki alasan tersendiri yang melatarbelakangi keputusan mereka untuk bekerja ke luar negeri. Faktor pendorong tersebut beragam dari satu individu dengan individu yang lain, mulai dari faktor ekonomi maupun mencari pengalaman.

Adanya motivasi untuk mengubah nasib maupun adanya daya tarik upah yang relatif tinggi di luar negeri mengakibatkan banyak tenaga kerja (khususnya perempuan) rela menjadi tenaga kerja di luar negeri, bahkan perempuan yang sudah bersuami pun banyak yang menjadi tenaga kerja wanita di luar negeri. Keputusan semacam ini diambil dengan harapan mampu membantu mencukupi kebutuhan keluarga yang selama ini masih kurang atau belum terpenuhi. Faktor kemiskinan menjadi faktor pendorong utama para perempuan menjadi TKW sebagai upaya mengatasi tekanan beban sosial ekonomi keluarga.

\section{F. Tenaga Kerja Wanita di Desa Tempur Kecamatan Keling Kabupaten Jepara}

Secara umum, pada masyarakat Desa Tempur Kecamatan Keling Kabupaten Jepara memandang bahwa menjadi TKW ke Luar Negeri adalah cara hidup di mana istri dalam mempertahankan kehidupannya dengan menjadi pembantu rumah tangga, yang artinya mata pencarian utama bahkan mata pencarian tunggal, bagi istri yang memandang menjadi Tenaga Kerja Wanita (TKW) adalah gaya hidup sebagai mata pencarian sampingan dalam memenuhi kebutuhan hidupnya. 
Luluk Sofiana dan Zahrotul N.A

Kondisi sekarang pada Desa Tempur Kecamatan Keling Kabupaten Jepara dalam suatu keluarga sudah mengalami peningkatan, dimana sebelumnya para masyarakat bahwa menjadi TKW hanya dari pengetahuan yang turun menurun. Kondisi sekarang para masyarakat dalam hal pekerjaan khususnya menjadi TKW ke Luar Negeri sudah mengoptimalkan pemakaian teknologi. Untuk melihat kehidupan keluarga TKW di Desa Tempur Kecamatan Keling Kabupaten Jepara dapat dilihat dari mata pencaharian keluarga atau dari pekerjaan suami. Karena dari sini dapat dilihat bahwa istri sebagai pencari nafkah utama dalam keluarga.

Dari hasil penelitian dapat diketahui bahwa jenis pekerjaan tersebut dapat dilihat pekerjaan suami adalah sebagai buruh bangunan, guru, dan petani. Selain itu ada beberapa di antara mereka yang tidak memiliki pekerjaan, tidak memiliki suami (janda), bahkan ada yang di tinggal oleh suami. Berikut ini adalah pentasarufan gaji istri selama menjadi TKW ke Luar Negeri ada dua keluarga di Desa tempur Kecamatan Keling Kabupaten Jepara.

Pertama, keluarga ibu Nur Khasanah dan suaminya (bapak sumari), mereka adalah orang Desa Tempur asli. Keluarga ini telah mempunyai dua orang anak, yang pertama umur 18 tahun, dan sudah bekerja di kota Demak sebagai kasir di sebuah rumah makan, dan yang kedua umur 6 tahun, ibu Nur Khasanah adalah lulusan Madrasah Aliyah Darul Falah Sirahan, sementara suaminya bapak Sumari adalah lulusan Sekolah Dasar 02 Tempur Keling Jepara. Setelah menikah ibu Nur Khasanah dan bapak Sumari secara ekonominya tergolong keluarga pas-pasan. ${ }^{26}$

Menurut keterangan ibu Nur Khasanah dari hasil wawancara penulis dengan beliau, suami ibu Nur Khasanah adalah seorang buruh bangunan, kondisi keluarga yang pas-pasan itulah kemudian yang mendorong ibu Nur Khasanah bekerja ke Luar Negeri sebagai TKW. Selama menjadi TKW di Arab Saudi selama tiga tahun, hasil kerja tersebut digunakan untuk membangun rumah dari hasil kerjanya tersebut diatas tanah pemberian orang tua bapak sumari. Begitu rumah sudah didirikan ibu Nur Khasanah berangkat lagi ke Arab Saudi, dua tahun pulang lagi dan gaji yang diperoleh ibu Nur Khasanah digunakan untuk memperbaiki rumah hingga sekarang rumah yang mereka

${ }^{26}$ Wawancara dengan Ibu Nur Khasanah tanggal 11 September 2018. 
tempati sudah layak, berpagar tembok, berkeramik, memiliki tiga kamar, dua kamar tidur, satu kamar untuk menyimpan beras dan lain-lain, satu ruang tamu, dan satu ruang tengah untuk kumpul keluarga menonton televisi dan satu dapur. ${ }^{27}$

Kedua, Ristiana anak kedua dari bapak Suwadi dan ibu Sumirah keluarga ini asli warga Desa Tempur Keling Jepara, mbak Ristiana belum menikah karena baru lulus Madrasah Tsanawiyah Mathali'ul Huda Tempur, dia hidup berdampingan dengan tetangga-tetangga, keseharian mbak Ristiana adalah bekerja sebagai penjual pulsa, usaha itu dimulai dari uang hasil bapaknya (bapak Suwadi) dari bertani. Setelah beberapa tahun ditekuni mbak Ristiana sebagai penjual pulsa, mbak Ristiana memutuskan untuk pergi ke Hongkong untuk menjadi TKW karena tergiur dari beberapa tetangganya yang sudah pernah pergi ke Luar Negeri menjadi TKW. Ristiana pergi bekerja ke Luar Negeri selama tiga tahun lalu cuti pulang ke Desa Tempur keling Jepara untuk menikah, lalu setelah menikah Ristiana pergi lagi ke Luar Negeri untuk meneruskan pekerjaannya selama dua tahun. Hasil kerja Ristiana yang pertama selama tiga tahun digunakan untuk resepsi pernikahan dan kebutuhan keluarga, dan hasil kerja yang kedua selama dua tahun digunakan untuk mencukupi kebutuhan sehari-hari bersama suaminya. ${ }^{28}$

Dari hasil penelitian dapat dilihat secara jelas tentang upaya pemenuhan kebutuhan nafkah keluarga TKW. Responden menunjukkan bahwa upaya pemenuhan kebutuhan tersebut diserahkan kepada suami dan orang tuanya.

Dari penelitian ini dapat dilihat tentang tasaruf gaji istri sebagai TKW untuk keluarganya. Responden menyebutkan bahwa uang hasil kerja menjadi TKW digunakan untuk memenuhi kebutuhan hidup sehari-hari, membiayai pendidikan anak, membangun rumah, merenovasi rumah, atau ada pula yang digunakan untuk membayar hutang. Berdasarkan hasil wawancara dengan responden dapat dilihat bahwa istri memiliki peran penting dalam keluarga. Dengan menekuni profesi sebagai TKW kebutuhan hidup sehari-hari, pendidikan anak, serta tempat tinggal dapat terpenuhi.

${ }^{27}$ Wawancara dengan Ibu Nur Khasanah tanggal 11 September 2018.

${ }^{28}$ Wawancara dengan Ristiana pada 11 September 2018. 
Luluk Sofiana dan Zahrotul N.A

\section{G. Penutup}

Berdasarkan hasil kajian dan analisis penulis terhadap hasil penelitian dapat diambil kesimpulan bahwa peran wanita menjadi pencari nafkah sebagai TKW dalam perspektif hukum Islam pada dasarnya diperbolehkan, dikarenakan mencari nafkah untuk mencukupi sarana kehidupan adalah hak dan kewajiban baik laki-laki maupun perempuan selama seorang istri tidak melalaikan kewajibannya terhadap suami dan anak-anaknya.

Peran wanita menjadi pencari nafkah sebagai TKW dalam perspektif hukum positif Indonesia juga diperbolehkan, dikarenakan seorang perempuan yang mampu melakukan kegiatan/pekerjaan baik di dalam maupun di luar hubungan kerja guna menghasilkan barang atau jasa untuk memenuhi kebutuhan sendiri maupun kebutuhan masyarakat.

Motivasi para istri menjadi TKW di Desa Tempur Kecamatan Keling Kabupaten Jepara adalah untuk memperbaiki kehidupan masa depan yang lebih baik dan memperbaiki taraf hidup bagi masa depan anak-anaknya kelak khususnya dari aspek ekonomi.

Kepada masyarakat, utamanya umat muslim yang telah terikat dalam sebuah ikatan pernikahan hendaklah saling menjaga keutuhan rumah tangganya dengan saling menjalankan kewajiban sebagai suami dan istri.

Kepada suami yang ditinggal istrinya menjadi TKW, sebaiknya memahami relasi suami istri dalam rumah tangga. Ketika suami tidak mampu memberi nafkah bagi keluarga sementara istri bekerja menjadi TKW sudah menjadi kenyataan yang harus diterima jika untuk sementara waktu pekerjaan dalam rumah tangga menjadi tanggung jawab yang harus dilaksanakan khususnya intuk merawat dan mendidik anak. 


\section{Daftar Pustaka}

Al-Qur'an.

Amin, Rusli. 2003, Rumabku Surgaku: Sukses Membangun Keluarga Islami, Jakarta: AlMawardi Prima.

Asqolani, Ibnu Hajar Al. Tinjauan Hukum Islam Terhadap Peran Istri Sebagai TKW Untuk Menunjang Nafkah Keluarga Di Desa Cimenteng Kecamatan Campaka Kabupaten Cianjur.

Asyhadie, Zaeni, 2015. Hukum Kerja: Hukum Ketenagakerjaan Bidang Hubungan Kerja, Jakarta: Rajawali Pers.

Athibi, Ukasyah. 1998, Wanita Mengapa Merosot Akhlaknya, Jakarta: Gena Insani.

Dahri, Ibnu Ahmad. 1992, Peran GandaW anita Modern, Jakarta: Al-Kausar.

Daradjad, Zakiyah. 1995, Ilmu Figh Jilid 2, Jakarta: Dana Bhakti Wakaf.

Gisymar, Sholeh. 2005, Kado Cinta Untuk Istri, Yogyakarta: Arina.

Hadi, Sutrisno. 1989, Metodologi Research.

Haris, Abdul. 2002, Memburu Ringgit Membagi Kemiskinan: Fakta di Balik Migrasi Orang Sasak ke Malaysia, Yogyakarta: Pustaka Pelajar.

Hasmiana, H. 2004, Migrasi dan Ketahanan Keluarga, Jurnal Ilmu Sosial BidangPendidikan Mon Mata, Vol 6, Lembaga Penelitian Syiah Kuala Darusalam Banda Aceh.

Himpuanan Fatwa Majlis Ulama Indonesia. 2003, Bagian Proyek Sarana dan Prasarana Produk Halal, Direktur Jendral Bimbingan Masyarakat Islam dan Penyelenggaraan Haji Departemen Agama RI.

Irfan, Muhammad. Tinjauan Hukum Islam Terhadap Perusahaan Jasa Tenaga Kerja Indonesia Dalam Upaya Perlindungan Tenaga Kerja di Luar Negeri (Studi Kasus di PT.PJTKI)

Jaziri, Abdur Rohman Al. 1969, Kitab Fiqh Al-Madzabib Al-Arba'ah, (juz 4, Al-Maktabah, Al-Tijariyyah Al-Kubro, Mesir.

Kompilasi Hukum Islam

Moleong, Lexy J.1993, Metodologi Penelitian Kualitatif. Bandung: PT. Remaja Roskarya.

Muhammad, Imam Qudzi Abu Walid, Bidayatul Mujtahid, Mesir: Dar Al-Fikr.

Mulyati, Sri. 2004, Relasi Suami Dalam Islam, Jakarta: Pusat Studi Wanita, (PSW), UIN Syarif hidayatullah. 
Luluk Sofiana dan Zahrotul N.A

Munti, Ratna Batara. 1999, Perempuan Sebagai Kepala Rumab Tangga. Diterbitkan atas Kerja Sama Lembaga Kajian Agama dan Jender, Jakarta: Solidaritas Perempuan.

Nafis, Cholil. Fikih Keluarga, Menuju Keluarga Sakinah, Mawaddah, Warohmah. Keluarga Sehat, Sejabtera Dan Berkualitas. (Jakarta Selatan: Mitra Abadi Press.

Nasution, Amir Taat. 1994, Rabasia Perkawinan Dalam Islam: Tuntunan Keluarga Babagia, (Jakarta: Pedoman Ilmu Jaya.

Nazir, Moh.1988, Metode Penelitian. Jakarta: Ghalia Indonesia.

Nurjannah, Siti. 2008, Persepsi Migran W anita Terhadap Migrasi Keluar Negeri dan Dampaknya Terbadap Perubahan Sosial di Pedesaan, Skripsi, Semarang: Universitas Diponegoro.

Rahman, Asjmuni A. 1976, Qaidah-qaidah Fiqh (Qwaidul FIqbiyah), Jakarta, Bulan Bintang.

Rosikhoh, Ikho. Perlindungan Tenaga Kerja Wanita Dalam Perspektif Hukum Islam (studi kasus pada PT. Sandratex (iputat).

Sabiq, Sayyid, Fiqih Sunnah Jilid VII, Terjemah Fiqib Sunnah, Bandung, PT. Al Ma'arif, t.t

Shihab, M. Quraish. 2000, Wawasan Al-Qur'an, Cetakan Ke-11, Bandung: Mizan.

Soekanto, Soerjono. 1986, Pengantar Penelitian Hukum. Jakarta: UI Press

Syarifudin, Amir. 2006, Hukum Perkawinan di Indonesia Antara Fiqib Munaqahat dan Undang-Undang Perkawinan, Jakarta: Kencana.

Tauhid, Lembaga Darut. 1990, Kiprah Muslimah Dalam Keluarga Islam, Terj. A. Chumaidi Umar, Bandung: Mizan.

Thalib, Muhammad, Ketentuan nafkah Istri dan Anak.

Ulfah, Maria. Tinjauan Hukum Islam Terhadap Hak-Hak. Tenaga Kerja Wanita

Undang-Undang Ketenagakerjaan Nomor 13 Tahun 2003.

Undang-Undang Perkawinan di Indonesia, Arkola, Surabaya.

Vadlun, Fadlia. 2010, Migrasi Wanita dan Ketahanan Ekonomi Keluarga, Skripsi, Semarang:

Universitas Diponegoro. 